\title{
The Unstable Coastline: Navigating Dispossession and Belonging in Colombo
}

\begin{abstract}
Alessandra Radicati
This article explores how residents of a small coastal fishing enclave in Colombo live with cumulative waves of dispossession brought on by exclusionary projects of urban development. Drawing on ethnographic fieldwork, I introduce the analytic of navigation to describe how people move, plan and live with both present and future threats of dispossession. Navigation offers a unique perspective on questions of agency and resistance in oppressive conditions. Rather than framing subjects as "resisting" projects of world-class city-making, this analysis shows that urban residents instead engage in complex and occasionally contradictory modes of living with uncertainty. I complicate existing understandings of the term "navigation" by describing how questions of nation and belonging are crucial to comprehending how people navigate. Ultimately, I suggest that expressions of belonging and obligation to an imagined community might not only be strategic, but instead reflect some of the broader social forces which structure possibilities for action.
\end{abstract}

Key Words: Dispossession; Navigation; Global Cities; World Class Cities; Nation; Belonging; Coastal; Sri Lanka

\section{Introduction}

One morning in August 2015, I talked with William, a fisherman, outside of his house in Mutuwall, a coastal neighborhood of northern Colombo.i In the narrow concrete walkway which ran through the neighborhood, only a few feet away from the ocean waves, I sat on a plastic chair while William sat on a low stool. We were talking about his recent fishing excursions, and what the catch was like at this time of year. But he was not looking directly at me or making eye contact - instead, William was preoccupied with another task, scrawling a series of numbers on his forearms with a pen. The numbers came from a borrowed GPS device, which William had removed from a plastic case; he was entering the coordinates of maritime locations where other fishermen in the area had recently had success finding decent catches. "We follow the fish, the fish don't come to us," he explained as he etched the numbers on his flesh in black ink.

As I got to know William, our conversations vividly illustrated the kinds of struggles fishers in this part of Colombo face, and the personal and professional trajectories available to 
them in the context of rapid urban development. William's stories blended together common elements that emerged time and time again in my conversations with Mutuwall residents: the difficulties of making ends meet; the effects of the 2004 tsunami; seemingly never-ending cycles of debt; and worries about the future of fishing as a viable livelihood. All of these factors point to a general depletion of social and material resources, and gesture at the multiple vectors of dispossession (Fernandez 2017) which people like William face. Contemporary dispossession, as it is lived and experienced by real people, is often messy and confusing, taking place at different scales and along different timelines (Li 2009, Harms 2013). Through my conversations with William and others in Mutuwall, it became clear that even enumerating and articulating the different strands of dispossession that the community faced was a challenge (Zeiderman 2016, Fernandez 2017).

Mutuwall is a small neighborhood located near the Port of Colombo, home to poor and working-class families who work in either fishing or what residents term "land jobs," such as masonry, industrial labor, or small informal businesses. William and his friends and neighbors navigate multiple, simultaneous and overlapping forms of dispossession. These include (1) potential displacement from the coastal land they inhabit; (2) threats to marine life and declining catch for fishermen, who make up a significant portion of Mutuwall's population; (3) social alienation and exclusion from post-war Colombo's elite landscape. As I describe more in detail in this article, relocation and displacement are multi-faceted: Mutuwall residents lived with the possibility of eviction from coastal land which could be carried out for a variety of different reasons, and along different timelines. Confusion regarding potential compensation from the state and residents' lack of clear legal claims to their homes made it difficult, if not impossible, to anticipate what their futures would look like should they be evicted. 
In this essay, I argue that rather than being resisted, eviction and other forms of dispossession are, instead, navigated in various ways by urban residents. Drawing on ethnographic research conducted in 2015 and 2016 among residents of Mutuwall, I further show that this navigation is, at least in part, mediated through expressions of national belonging, loyalty and citizenship that make outright resistance and conflict rare. This draws attention to the fact that even subaltern citizens in Sri Lanka are deeply invested in Sinhala nationalism. The ethnographic material presented in this paper suggests that dispossession in urban contexts is not only economic or material in nature, but also intimately connected to symbolic and affective questions of citizenship, belonging and loyalty to the postcolonial state.

William's comment about following the fish and his absorption in the task of inscribing GPS coordinates on his body call attention to the concept of "navigation." Beyond the obvious maritime resonance of the term, I suggest it is a useful analytic for understanding how my informants deal with the highly uncertain realities they inhabit. Navigation can refer to "the ways in which different people actively move through, practice, cope with, seek to dominate, and learn how to live in the city" (McFarlane and Anjaria 2011, 7). My ethnography emphasizes the shifting circumstances of life in Colombo which inflect Mutuwall residents' sense of possibility; in this, I am particularly inspired by Henrik Vigh's understanding of navigation as “a special form of movement: that is, the way we move in a moving environment... an analytical optic which allows us to focus on how people move and manage within situations of social flux and change" $(2009,420)$. My ethnographic material suggests that in the context of post-war Colombo, negotiation with state agencies was not possible, as dispossession often came about in highly impersonal and top-down ways. Instead of negotiating with more powerful actors and institutions, fishers like William can only navigate circumstances beyond their control. 
Navigation suggests a unique relationship to the concept of resistance; while in scholarly analyses "resistance" typically suggests acts of contestation that pit individuals against the power of states or institutions, here the resistance that matters stems from the social field itself.ii Figuratively and literally, William and others like him are dragged backwards, propelled forwards and buffeted by waves of hardship. They possess agency and skill; as I describe in what follows, they use a range of techniques to "get by" in difficult circumstances. But most Mutuwall residents do not engage in protest, or make many formal demands. Rather, they use their abilities to adapt to increasingly uncertain circumstances, and to assert their loyalty to the Sinhala-Buddhist nation.

Colombo has much to contribute to the generation of urban theory from the South. Amidst important discussions in urban geography and urban studies about where our theories of the urban come from - and where they might be going (Jazeel 2017, Roy 2011, Roy and Ong 2011, Simone 2016, Zeiderman 2018)- it is clear that Global South cities cannot be understood by imposing Eurocentric assumptions. But it is equally clear that not all Global South cities have received the same amount of attention. The emphasis in my analysis on rhetorics of nationalism and concomitant forms of navigation deployed by the soon-to-be-dispossessed is particularly relevant in the Sri Lankan context, in which many facets of life have been shaped by forces which appear to be separate from political-economic analytics such as "dispossession," but in fact are entangled with them. From Colombo we learn that material realities of eviction and displacement and questions about the nature of belonging, citizenship and nationhood can and must be understood as linked.

In drawing attention to the ways Mutuwall residents navigate dispossession, I take inspiration from recent studies which have examined subtle forms of compliance, consent and 
acceptance which characterize urban residents' ways of relating to oppressive conditions (eg. Harms 2012 and 2013, Zeiderman 2016, Melly 2013, Pettit 2018, de Boeck 2011, Harker 2011, Allen 2008). The lens of navigation, as I use it, highlights both temporal and spatial dimensions of dispossession which are familiar from other accounts of urban displacement in the scholarly literature, but also diverge from it in important ways. Specifically, navigation calls attention to the limits of individual agency and to the enmeshment of present and future concerns in Mutuwall residents' accounts; it offers a way of looking at dispossession and displacement as they relate to notions of citizenship and belonging to the nation-state. Navigation also foregrounds the complex forms of movement and mobility involved in both maritime and landbased strategies for coping with displacement.iii

In order to build my argument, I begin by situating Mutuwall residents' struggles within the broader context of post-war urban development in Colombo. Next, I describe how residents make sense of and think about different waves of dispossession which occur along disjointed timelines. I then turn to a description of how William, introduced above, navigated these waves. In the following section, I consider William and other residents' expressions of loyalty to the state as a reason for the lack of outward resistance in the area. The final section offers theoretical reflections on how the navigation I describe in Mutuwall both reflects and diverges from other experiences of displacement in the scholarly literature.

\section{In Between: Post-War in Progress}

"We don't know whether our houses will be demolished. We are in-between." Delilah, a woman in her forties from Mutuwall, spoke these words one afternoon in June 2016. Delilah lives in one of the largest, most elaborate houses in the area. Her husband works as a mason, and 
built much of the house himself from the ground up. Delilah's living room was full of framed pictures of family members of all ages at weddings, baptisms, and other celebrations. As we talked, her children, nieces and nephews came in and out of the house, casually greeting us. The thought of her home being destroyed filled the air with an indelible sadness. We were discussing rumors that fishers in Mutuwall might be evicted, rumors which had been going around for some time. Delilah and her neighbors had heard about various plans to relocate them over the years, but as their continued presence in the area attests, these plans had not come to fruition. The postwar moment in Colombo is a "work in progress" (Amarasuriya and Spencer 2015). For people like Delilah who stand to lose their homes, this "work in progress" translates into confusion about the futures available to them, and uneasy modes of inhabiting the present.

Delilah's comment speaks to the uncertainty which many of Colombo's urban poor communities have experienced over the last decade. Under the leadership of Gothabaya Rajapakse, brother of President Mahinda Rajapakse, urban development in Colombo was topdown and authoritarian in nature, as well as being highly militarized; in 2010, the Ministry of Defense became the Ministry of Defense and Urban Development. The Urban Development Authority (UDA) has been the main implementing body carrying out Ministry directives under the broad agendas of the Urban Regeneration Project (URP) and Metro Colombo Urban Development Project, which aimed to "open up" land occupied by low-income city residents by relocating them to high-rise buildings. Displacement of urban residents to make use of desirable land in central Colombo has become increasingly common, with much evidence to suggest that the flats provided by the UDA are poorly maintained, costly, and offer an overall worse quality of life for relocated residents (CPA 2014 and Perera 2016). 
These projects are part of a broader agenda of "world-class city-making" (Ghertner 2015) in Colombo. Since the end of the civil war in May 2009, ambitious rhetoric from state officials positions the city as a potential rival to Asian metropolises such as Dubai or Singapore, with a view to attracting not only tourists but also waves of foreign investors. The Sri Lankan capital has seen seemingly endless construction and renovation of luxury retail, leisure and residential complexes; extensive projects aimed at improving the city's roads; and the initiation of the Colombo Port City project, a Chinese-funded waterfront development worth $\$ 1.4$ billion USD, representing the largest-ever foreign investment in Sri Lanka's economy. Begun under President Mahinda Rajapakse and continued by the successive government which took power in January 2015, dramatic transformations of Colombo's social, physical and economic landscapes continue apace.

Like other members of the urban poor, fishers in Mutuwall are not only excluded from these projects of world-class city-making but are actively imperiled by them. In 2014, the Centre for Policy Alternatives, a Colombo think-tank, termed mass evictions of the urban poor "the ugly price of beautification," estimating that government plans to relocate between 70,000 and 135,000 families would result in the displacement of "anywhere between 280,000 to over 500,000 people" (CPA 2014, 9). Understood in relation to Colombo's overall population of roughly two million, these numbers are striking.iv As Sasanka Perera notes, "a relocation of people of this magnitude in an urban space in Sri Lanka has not been recorded in recent history" $(2018,31)$. For Mutuwall residents, relocation signals not only eviction from their homes, but also displacement from the coastline, a source of income for many in the area. Eviction would not only threaten material wealth, but the social ties and networks which have been built up in Mutuwall over time. 
But Delilah's description of being "in-between" indexes a very particular moment of transition in Colombo's post-war decade. While the heavy-handed approach of the Rajapakse administration has been documented by scholars, think-tanks and local NGOs (eg. Perera 2018, CPA 2014, Perera 2016, Amarasuriya and Spencer 2015), what has been overlooked has been the additional confusion brought on by the political transition of 2015. In January of that year, Rajapakse was democratically ousted from power in a highly surprising election result. A coalition government led by President Maithripala Sirisena and Prime Minister Ranil Wickremasinghe came to power, promising greater levels of transparency and accountability, and vowing to halt certain large-scale projects, like the Port City, which had been initiated under the Rajapakses. While these promises seemed to point to less draconian modes of enacting urban development in Colombo, suggesting a move away from the practice of large-scale evictions, the change in government did not necessarily reflect a change in the power dynamics between urban residents and the UDA. Often referring to state agencies and politicians as actors which could abruptly change their minds at any moment, Mutuwall residents frequently speculated about the motivations and larger aims of these distant but powerful entities, wondering what would happen. Decisions which played out on a national scale - such as increased taxes and the raging debates over the Port City - affected them intimately, but impersonally in that Mutuwall fishers were not a broadly recognized political constituency with the power to influence policy-makers. After all, Delilah's worries about her house being demolished were expressed in 2016 - over a year after the new government had come to power. The more things changed, the more they stayed the same.

The research for this article took place in the midst of this transitional and highly uncertain political moment. My ethnography unfolded over 12 months in 2015 and 2016 and involved 
engaged observation, informal conversations and semi-structured interviews with residents.

Because Mutuwall is not an officially recognized, self-contained neighborhood within Colombo, it is difficult to come across accurate population statistics for the enclave. My informants themselves estimated the population of the fishing enclave to be about 200. The observations and conversations related here emerge from engagement with around 20 different individuals across different families in Mutuwall, including men, women, and children - fishers and non-fishers. Of these, about seven or eight individuals were consulted on a regular basis through social visits, conversations in their homes and casual run-ins. The findings and insights related here benefit from being anchored within a broader ethnographic project, which allowed me to contextualize my observations in relation to the wider sweep of rapid urban change taking place in Colombo.v

\section{Waves of Dispossession}

Amidst the confusion and "in-between" nature of Colombo's post-war urban transformation, residents of Mutuwall navigate "incremental, under-the-radar" (Fernandez 2017, 159) forms of dispossession. This section conceives of various projects of urban development as accretive rather than discrete forms of harm. Like waves eroding the narrow beach at Mutuwall, each project builds on the damage done by the one before. Two particular waves of potential dispossession stand out: the effects of the Colombo Port City project, and a pre-Port City relocation scheme.vi Crucially, each wave still looms on the horizon in a state of constantly shifting possibility.

Inaugurated in September 2014 by President Rajapakse and Chinese President Xi Jinping the Colombo Port City project has little to do with Colombo's working, industrial port. The Port City is to be built on a new island of reclaimed land which will face Colombo's existing downtown business district, and will include luxury high rise apartment buildings, shopping malls housing 
international brands, and a dedicated transportation hub. The Port City was the subject of intense debate and political controversy in Sri Lanka during the time of my fieldwork. Because it symbolized efforts under the Rajapakse government to build closer relationships with China as part of the One Belt One Road initiative, the project was placed on hold by the new government for much of 2015. But ultimately, it was allowed to go ahead towards the end of the year further evidence that the state's urban development agenda had many elements of continuity rather than rupture between the Rajapakse and coalition governments.

Mass demonstrations had been organized against the project in early 2015, bringing together fishers, environmentalists and various religious figures. As I describe later, however, not only did the protests fail, many of the fishers I came to know expressed ambivalence about any overt political action despite the Port City's potentially disastrous consequences. The Port City's potential disruption to marine livelihoods was foremost on the minds of fishers. Fishermen were concerned that the ongoing construction and dredging of sand would add to already high levels of coastal erosion, literally making the land on which their houses were built disappear over time. Combined with the anticipated decline in fish populations who would have a harder time laying eggs and reproducing in increasingly murky and trafficked waters, many fishermen were convinced that even without formal orders to relocate, the very act of constructing the Port City would make fishing impossible, thereby pushing Mutuwall residents off their land even without official eviction notices.

Some Mutuwall residents framed their opposition to the Port City project not solely in ecological terms related to marine life and diminished catch, but also in social terms of class conflict. As Anura, one of the younger fishermen in Mutuwall told me: if "rich people come here, they will call the police on us;" with a new luxury island being constructed so close to the 
most fertile fishing areas, fishers worried that upper-class residents of the Port City's glittering new apartment buildings would react with fear at the sight of fishermen, who were visually marked as lower-class.vii A middle-aged woman said: “we've been going to the Galle Face Green since our grandparents' time, now we are afraid our children will not be able to go there." The clearly exclusionary nature of the Port City was not lost on Mutuwall residents, who experienced dispossession both in both social and material registers.

The possibility of receiving compensation for damages caused by the Port City project was unclear, and unappealing to most Mutuwall residents who were certain that this would not truly reimburse them for their losses. An expert report critical of the government's various Environmental Impact Assessments noted that even with 500 million rupees earmarked for compensation to fishing communities over ten years, this would provide affected families under five rupees (\$0.03 USD) per day. “The Port City people may give compensation, but it won’t last long. It will be a one-time sum and only last a few months. They should give us a monthly salary" said Anura, skeptical that any form of compensation would do justice to the fishermen's losses. For Peter, a fisherman in his fifties and father to three young girls, compensation in any form would be insufficient: "we don't care what they give, we will never leave this area. Our whole life is here, if they ask us not to fish, how can we live?"

But there had been another wave of (potential) displacement before September 2014. Because I had initially come to Mutuwall as part of my research on the Port City, I assumed that its construction was the main reason for fishers to fear eviction. I framed most of my questions along these lines, thinking that if the fishers could mobilize successfully against the Port City, there might be a chance for them to keep their homes. I soon learned, however, that this assumption was incorrect. Mutuwall was located on valuable land, a coastal location within easy 
sight of Colombo's primary business district, and in close proximity to the port. Because of this, whether or not the Port City project went ahead, in all likelihood the future of the area would not permit low-income fishers and laborers to continue living there.

A few months into my fieldwork in Mutuwall, I learned that plans for relocation were already underway before the Port City project was green-lighted, and before the change in government of January 2015. Delilah was the one who drew my attention to this one morning in summer 2015. As she swept her floor and then got around to the task of preparing lunch packets, we got onto the topic of the upcoming parliamentary elections: "I don't care, as long as the politicians let us be" was her opinion. Almost off-handedly, as she prepared a serving of curry, she said that the previous government was going to demolish these houses and move everybody into high rise apartment buildings. "Apartments are crap," she commented flatly, indicating that this was hardly an appealing option.

The potential relocation of the families in Mutuwall was supposedly motivated by the desire to create a new road to the port, but nothing actually came of the plan, and after the change in government no one knew whether this would go ahead or not. Legal protection from eviction seemed tenuous; one woman I spoke to told me she did not have a deed for her house, but brushed off concerns about being relocated by saying she possessed a "green card," a document indicating tenure. However, green cards, issued by the local municipal council, were not the same as deeds and they would not prevent someone from losing their home.viii Several others also confirmed that they did not have deeds - this included Delilah herself, who lived in the big, impressive house. Delilah remarked that "we don't mind [moving to a high rise] if we can have a quiet, normal life like here," since she pointed out "we do land jobs" and thus her family did not need to be next to the water. However, she also told us that they wouldn't be 
offered any compensation for moving, and expressed concern over whether a new apartment would even be able to accommodate her family of eight people.

The prospect of being relocated was a cause for real concern among other Mutuwall residents I spoke to, mainly those who did rely on fishing as a primary source of income. Speaking with Darius, a fisherman in his fifties, I asked about relocation plans for the area. He told me that "around two years ago" some government representatives came by to talk about it. They put a sticker on the door of each house marked for relocation, and told them they would get a new house. But that was two years ago, he repeated, and they weren't given any details of where the new housing would be. "Look, you can see it right there," Darius said, gesturing casually towards his front door. I got up and looked for the sticker -it was small, a ragged dirty sticker with a letter "P" on it. It was just one of many stickers on a door littered with images of Pope Francis and Jesus Christ. "The only thing I know is fishing," Darius said when I came back. 'I didn't study. I need a house somewhere close to the beach. After all, I have to take care of my children."

My conversations on potential eviction or relocation revealed the extent to which confusion reigned in Mutuwall, and suggests the complexity of the processes of dispossession residents faced. No one knew why they might be relocated (for a road, or to build other kinds of houses, or because of the Port City's eventual completion, or some combination of the three). In our discussions, my informants did not seem particularly concerned about which of these specific reasons would lead to their eventual displacement - if anything, the overlapping and multifaceted nature of the threats they faced pointed to the singular nature of dispossession in this context. If one project did not go ahead, another might - the unifying logic was the same, and 
always pointed to the fact that no matter what, Mutuwall residents would not be able to inhabit their homes for very long.ix

Recent scholarship has complicated our understandings of dispossession, pointing to its disjointed spatialities and temporalities (Li 2009, Harms 2013) and its multiple natures and differential impacts both across and within communities (Fernandez 2017, Doshi 2013, Harms 2013). The erasure - both symbolically and materially - of poor people from the urban landscape has been a feature of global and "world-class" city-making efforts across different world regions and has been well-documented by scholars and activists critical of the triumphalist narratives of municipal and state governments (eg. Baviskar 2002, Ghertner 2015, Fernandes 2006, Roy 2009 and 2016, Goldman 2011). While many studies have pointed to the material effects of such erasure, i.e., the literal removal and eviction of urban residents from desirable "downtown" areas of various cities, others have called attention to the symbolic and aesthetic elements of such efforts (Ghertner 2015, Fernandes 2006). Whether through a "politics of forgetting” (Fernandes 2006) or through the imprecise yet powerful aspiration to live in a world-class city (Ghertner 2015), it is clear that eviction and dispossession serve not only to facilitate material forms of accumulation, but also shape - and are shaped by - immaterial forces of desire, uncertainty and fear.

I maintain the use of the broader term "dispossession" rather than narrowing my focus to simple "eviction" because, as shown, relocation impacts not only place of residence but also economic activity and social ties. Dispossession is experienced across material and affective registers, and encompasses both actual and potential forms of eviction, alienation and loss. It is this mix of actual and potential, current and future - or, in Delilah's words - being "in-between" which makes the optic of navigation important. Mutuwall residents not only dealt with actually 
occurring dispossession, but had to spend a significant amount of time considering how shifting circumstances might affect them in the future. In what follows, I demonstrate how one fisherman in Mutuwall navigated these different waves of dispossession.

\section{Following the Fish}

We follow the fish, the fish don't come to us. What struck me about William's words, related in the opening of this article, was their description of a very particular kind of movement through space. "Following" for William involved making his way through coastal waters and drawing on his boating and navigation skills; but in following the fish, he was restricted to their patterns of movement. William's goal was to get a good catch, and in pursuing the fish he had to be willing to go wherever they would lead. In this sense, navigation highlights that "we are never completely free to move as we want...we move in relation to the push and pulls, influence and imperatives of social forces" (Vigh 2009, 432). Distinct from strategy or tactics, navigation emphasizes the lack of control subjects face as they move through the world.

William's experiences illustrate how waves of dispossession accumulate in the life of a single individual; they also highlight a distinct attitude towards these waves, one marked by fairly muted objections. Like his neighbors, William had heard of plans to relocate the Mutuwall population and was skeptical, but he seemed more resigned than angry. "Why doesn't the government at least allow us to keep our boats here, as a docking station? This would be more practical," he said. They would also need some form of reimbursement for the cost of traveling from their new residences to the waterfront; while William did not object to the high-rise idea per se, he saw mounting costs and financial burdens that would have to be shouldered by the 
fishers. There was a rumor that even being relocated into one of the high rises would incur a charge, of Rs.50,000 (about \$300 USD). "I don’t have that," he said flatly.

On one occasion when speaking with William, his son came out to play. He steered a red tricycle with wheels that lit up as it moved. For a moment, we stood transfixed by the toy and the little boy's obvious delight. Never taking his eyes off the flashing wheels, William commented that when he was little, his father would never have been able to afford such a thing. "I don't want my children, my sons, to become fishermen," he said heavily. "I want a better life for my kids. We used to have enough money to enjoy Christmas, now it's difficult with no more fish to catch. One day, my children will have to eat imported fish," (piti rate malu) he said with sad irony.

In June 2016, when I returned to Mutuwall, William was never at home. The door to his house, always recognizable to me because it was decorated with Buddhist and Catholic imagery, was uncharacteristically shut in the middle of the day, and there was no sign of his family. Eventually, the wife of another fisherman I had interviewed told us the reason for William's absence was a new job: he was working construction for one of the new hotels being built by the Galle Face Green, next to the site of the Port City. As a result, instead of following the typical fisherman's schedule of going out to sea at night and returning in the very early morning, William followed a new schedule and was not available during the day.

William's trajectory from fishing to construction underscores that experiences of dispossession in this part of Colombo relate to both eviction from dwelling places and to occupation and economic activity. It illustrates the growing sense of futility and lack of opportunity associated with fishing, even as residents continued to fish because it was still a job they knew how to do. William's statement about his children eating imported fish was especially 
poignant in light of the fears, raised by many critics of the Port City, that the project would undermine Sri Lankan sovereignty. There was a tragic irony to William working in construction. While fishers in the area frequently recounted to me their previous experiences working in different types of "land jobs" - such as factory work, meat-packing, or agriculture - during times of particular economic hardship, the choice to work construction for one of the large hotels at the Galle Face Green represented participation in the very projects of urban development making life harder for Mutuwall residents.

There is an ambiguous coda to William's story, however: when I returned to Mutuwall briefly in April 2019, William was back to fishing - he even had a new boat. I was surprised, and asked some questions about how the purchase had come about; it turned out it was made possible by his wife moving to Saudi Arabia for two years to work as a domestic servant. Changing jobs, migrating, altering family relationships so that one person could leave and another could stay behind - these were all ways in which people navigated the waves of dispossession washing over Mutuwall. But what emerged clearly in my conversations with William was the fact that none of his strategies involved protest, or even much complaint. His idea of fishers using the site of their former homes as a docking station in the event of relocation had the speculative air of an attempt at negotiating with the (unhearing) state, but stopped shy of offering any resistance to it.

William's seeming to accept these increasingly precarious conditions surprised me, especially in light of the occasional but heated protests which were being organized against the Port City, and the deep feelings of disappointment and sadness which came across in our interactions. His mix of subdued complaint and quiet endurance (Harker forthcoming) also seemed to diverge from the expectations of much scholarly work in urban studies and social theory more broadly. Instead of claims and demands (eg. Butler and Athanasiou 2013) in the 
face of dispossession, Mutuwall residents like William seemed to simply accept that life was getting harder and that they had to change to adapt to these shifting circumstances. Literature on global or "world-class" city-making and displacement has tended to focus on residents' demands for inclusion and/or organized resistance in the face of exclusionary projects of urban development (eg.Doshi 2013, Ghertner 2015), or practices of "insurgent citizenship" (Holston 2009).x What I found in Mutuwall spoke to a considerably different reality. Rather than charting how seemingly incoherent or isolated acts might be considered examples of "resistance in emergence" (Hughes 2019), the remaining sections of this paper explore why and how things that initially looked and sounded like "resistance" masked deeper loyalty to the Sri Lankan state.

\section{Thinking of the Country}

On a quiet Friday morning when most fishers were asleep after a night at sea, I was speaking to Daniel, Darius' father, about the Port City project. I was asking him about his willingness to attend protests against the project, which were typically organized by religious institutions and NGOs. Daniel, I knew from previous encounters, was vehemently opposed to the Port City. But on this day, towards the end of one of his lengthy tirades about the project's many potential dangers, he mused that even though fishers would likely lose their livelihoods, "we cannot think only of our stomachs," (bada gine hitala) and sighed with resignation, saying that if the Port City was "for the good of the country" (ratete honday) then fishermen needed to find a way to accept it.xi

Daniel's remarks suggest a distinct way of understanding why and how Mutuwall fishermen carry on navigating an uncertain situation without engaging in obvious forms of protest or resistance. It frames the project as good for the broader Sri Lankan nation, and assumes that 
fishers must be loyal to this wider community, even when it is detrimental to their own wellbeing. This was not only surprising me as an outsider-ethnographer, but also suggested tensions between Mutuwall fishers and others determined to engage in more direct confrontation with the state.

The first time I had come to Mutuwall, I had been brought by activists in the People's Movement Against the Port City. These activists saw the Mutuwall fishers as natural allies, because of the obvious negative consequences that the project would have for their livelihoods. Initially, fishers attended some of these protests, and as previously demonstrated, many of them spoke firmly about their opposition to the project moving forward, or their unwillingness to accept any compensation as sufficient to replace the material and symbolic loss of claim to the coastline. But while many of the activists against the Port City engaged in strident critiques of the Sri Lankan state and tried to build multi-ethnic, multi-religious coalitions, often describing solidarity with Tamils and other minorities, the people I came to know in Mutuwall stopped short of engaging in these broader discussions.xii Some, like Daniel himself, had attended protests in the past but then decided to stop. Being "against" specific projects of urban development did not necessarily translate into being "against" the Sri Lankan state, or its nationalist-developmental rhetoric.

Daniel's comments were not unusual in Mutuwall. In fact, as my research continued, more people eventually expressed similar hesitations about outright resistance to the Port City, arguing instead for acceptance. William told me during one of our conversations that while he opposed the Port City project and hoped it wouldn't go ahead, it was important to him that Sinhalese people stick together; he said that "everyone else" and "other people" (meaning Muslims and Tamils) looked after one another but that only Sinhalese people failed to show 
unity, reverting instead to petty rivalries and jealousy. He even drew a link between my own research and this phenomenon, gesturing and moving his head in the direction of the neighbors' houses. He said that they probably wondered why I had chosen to interview him instead of them, and were likely looking on with envy.

Because of what he believed to be a deeply rooted inability to work together, William thought that the Sinhalese were fundamentally at a disadvantage compared with the supposedly more unified Tamils and Muslims. But to my surprise, William said that despite the fact that the government "does nothing" for the fishermen, "we [fishermen] have to think of the country" (rate hitanne) when protesting or complaining about development projects which might negatively impact them. Even when relating stories of brutal treatment he had received at the hands of Sri Lankan Navy officers patrolling the waters around or Colombo, or complaining of his frustrations with the government, William would punctuate his accounts with assertions that "they know what they are doing" or "they [the previous government] saved the country" from civil war.

Delilah too echoed these comments. She had always been adamant that the state "does nothing to help the poor." Nevertheless, she alternated complaints and harrowing stories with declarations of her gratitude and appreciation to the former government for having won the war. "Soon this country will belong to the Muslims and the Tamils!" she exclaimed more than once with an air of exasperation. Despite the fact that most of my Sinhalese interlocutors were religious minorities themselves (Catholics), and/or were of partial Tamil descent, and despite their own clear marginalization in the context of aspirational urban development projects in Colombo, it became evident that identification with Sinhalese-ness was still meaningful to them. As I have argued elsewhere, religion, mixed ethnic lineage and economic marginalization did not 
translate into Mutuwall residents rejecting Sinhala-Buddhist nationalist tropes, but rather stretched the very category of "Sinhalese-ness" (Radicati 2019).

It is beyond the scope of this article to offer a deep engagement with the extensive historical and sociological debates surrounding Sinhala-Buddhist nationalism, one of the most controversial and charged areas of scholarship on Sri Lanka.xiii My aim in this paper is not necessarily to delve into the specificities of how Mutuwall fishers do or do not fit into broader understandings of the Sinhala-Buddhist nation. Rather, my objective is to flag that nationalist sentiment and sense of belonging co-exist alongside dispossession, and appear - from the fishers' own words - to lead to fairly muted expressions of resistance, even towards projects that would gravely endanger their livelihoods.

Many studies of Sri Lankan politics have positioned Sinhala-Buddhist nationalism as an elite-manufactured phenomenon, one which naturally stands in opposition to the interests of subaltern citizens of Sri Lanka (eg., De Votta 2004, Jeganathan and Ismail 1995). But such an instrumental view of nationalism has serious shortcomings, particularly in its failure to understand how it continues to thrive and appeal even to Sri Lankans who seem not benefit from it at all. As David Rampton suggests:

It is no longer solely elites who share this social imaginary of Sri Lankan space as Sinhala Buddhist or the state vehicle which drives nationalism [...] such an analysis is completely lacking in an understanding of hegemony and the way that subaltern forces themselves may be drawn into and proactively reproduce nationalist discourse. This approach also neglects, by stressing the 'superfluousness' of nationalist discourse, the clearly generative, constructive and integrative force of nationalism. (2011, 254-255)

Through this Gramscian lens on Sinhala-Buddhist nationalism, it becomes possible to understand the perspectives of Mutuwall residents unwilling to challenge nationalist discourse, and even "proactively reproducing" it. Even as marginal residents of both the city and the SinhalaBuddhist nation, fishers are nonetheless fully interpellated into the dominant ideology of Sinhalese nationalism. 
I can only speculate as to whether or not my informants "really" meant what they said about thinking of the greater good of the country. However, for a number of reasons I would caution against reading the words of Daniel, William and Delilah as simply strategic utterances.xiv First, the highly uncertain nature of national politics at the time of these conversations meant that there were credible alternatives to reluctantly supporting the Port City. As discussed, activists were mobilizing against the project, and given that there still appeared to be a chance of it being halted, it was especially striking to hear people fill in their own justifications of the project being "for the good of the country." Second, my interlocutors did not foreground these comments in our discussions - they were presented instead as quiet musings woven through the rest of our conversations, which usually took place after I had known each person for quite a while. Particularly notable was that these musings often occurred at the end of longer discussions in which the person I spoke to related long lists of complaints about the government, and/or - in the cases of William and Daniel - described engagement in illegal activities of various kinds to help make ends meet. These were hardly the stories of people trying to present a virtuous front as unimpeachable, law-abiding citizens.

This brings me to the final reason I found such utterances to be not only compelling, but most likely sincere: the state was largely absent, and these comments were made in a context where, figuratively speaking, no one from the government could "hear" Mutuwall residents expressing their loyalty to the former president, or to the nation.xv Part of the confusion surrounding the different waves of dispossession that Mutuwall residents experienced stemmed precisely from the fact that state agencies did not hold public hearings or communicate clearly what shape these projects would take, or what forms of compensation would be forthcoming. The Sri Lankan state functioned as an absent presence, usually described as an entity that could 
mete out violence in the form of abduction or beatings, but failed to provide forms of support and sustenance for the urban poor.

If navigation is about moving through a shifting environment in which "we act, adjust and attune our strategies and tactics in relation to the way we experience and imagine and anticipate the movement and influence of social forces," (Vigh 2009, 420) then protest might be understood as one of many tactics which can be started or stopped depending on the broader circumstances. But as elucidated above, I suggest that the words of my informants need to be understood slightly differently. Expressing a sense of belonging was not merely tactical, but appeared to index a sincere attitude of loyalty to the nation. In a context in which Sinhala-Buddhist nationalism is the strongest ideological current (Venugopal 2018), reactions to dispossession and displacement must be understood in relation to broader questions of citizenship and belonging. Sinhala nationalism is not merely a superficial set of ideas to be taken up or cast aside when convenient, but rather forms the very fabric of reality that Mutuwall residents navigate.

\section{Navigating Dispossession}

The analytic of "navigation," as developed by Vigh, denotes something deeper than conscious strategy or tactics. Navigation “works against an image of the 'agent' ... allowing us to illuminate agency without accepting the idea of an autonomous and absolute subject" (2009, 432). Navigation is thus a useful corrective to accounts of social life which assume "stable ground as an implicit premise" (Vigh 2009, 427). For this reason, navigation is important in understanding two unique facets of life for the Mutuwall residents I have introduced in this article: the constantly changing prospects for dispossession, and the lack of visible, overt resistance to this dispossession which theories more focused on individual agency might expect to find under the circumstances. Put slightly differently, my interlocutors navigate through, with 
and around two seemingly opposed social realities: on the one hand, their claims to being Sinhalese citizens of Sri Lanka and their professed patriotism, and on the other the reality of their own dispossession at the hands of the state. The understanding of navigation that I advance in this paper thus borrows heavily from Vigh while also expanding on his use of the term in an attempt to understand the role that nation and sense of belonging play in people's navigations.

In Sri Lanka, development has been the main agenda for the postcolonial state, and one of the most prominent ways that the state makes itself felt in everyday life (Tennekoon 1988, Brow 1996). This focus on national development and progress has shaped the policy of nearly every government administration since the 1940s, xvi and helps explain why there has been little meaningful change between the Rajapkse and coalition governments in the post-conflict period: development is understood as a linear, unidirectional process and can only take place within certain parameters. But development in the Sri Lankan context has never only been conceived of materially. The implicit subjects of development are Sinhala-Buddhists, usually understood to be agrarian peasants; the benefits of development are meant to consolidate Sinhala-Buddhist power and to celebrate a sense of shared history, excluding the island's minority ethnic and religious communities (Woost 1993, Brow 1990). In this context it is unsurprising to hear fishers associate even environmentally or socially costly development projects like the Port City with "the good of the country." Development as a collective project is understood to transcend individual and community experience.

In research on Dakar, Caroline Melly describes how the "everyday hardships wrought by infrastructural change" are understood as "temporary inconveniences and disruptions endured for the sake of the nation" $(2013,387-88)$. At the same time, according to Melly, Dakarois' "discourses of hardship" are "avowedly ahistorical and centered squarely on the individual" 
$(2013,387)$. Melly's analysis thus illuminates the complex interplays of nationalism and individualism that emerge in aspirational global cities; while the overall benefits of urban development are understood to be a credit to the broader nation, poorer urban residents are left to deal with change in individualized, atomized ways leaving very little room for collective action against disruptive projects of world-class city-making. Fishers in Mutuwall, as shown in the preceding section, often appear to accept these projects, using the collective rhetoric of nationalism to explain their acceptance, while coping with their effects at the level of the individual or family. Navigation, then, can be a useful concept for thinking across different scales, as it may index both individual patterns of movement, planning and anticipatory action, and points to the way groups or communities experience turbulent times together. After all, the boats docked in Mutuwall can be piloted alone, or friends and relations can pile into them, helping the captain to steer.

The analytic of navigation also draws attention to the way that present and future are entangled, as it indexes the way we "experience and imagine and anticipate" shifting social realities (Vigh 2009, 420 - italics mine). Compensation for those affected by urban displacement is one of the most important sites for mediating between the future and the present in contexts of rapid development. Compensation represents a negotiated process acted out in the present, which remunerates urban dwellers for hardships that will come about in the future. Working out compensation is a process of determining what will be enough to sustain people in years or decades to come - possibly their whole lives. For those potentially poised to receive compensation, the calculation is crucial because once agreed it will likely be impossible to bargain for more. In a situation clouded with as many uncertainties as those I have described in Mutuwall, discussions about compensation, unsurprisingly, reflected this lack of clarity. While 
some of my informants believed there would be no compensation at all from projects like the Port City, others claimed they would be given a sum of money; these rumors were in turn countered by the criticism that no sum of money would be adequate to replace the livelihood of fishers who had no training for any other kind of job. In all cases, potential compensation that might be awarded in the future - rather than concrete offers of specific sums of money - were the objects of discussion and anxiety.

In this way, people in Mutuwall remained in a state of constant "eviction time," in which "uncertainty is the rule rather than the exception" (Harms 2013, 350). But these speculative discussions usually took place privately, not in dialogue with representatives of the state. This, then, illuminates a crucial way that my ethnography of Mutuwall diverges from other studies of urban displacement and eviction: in Mutuwall, the possibility of compensation remains so unclear that it can neither be harnessed for personal gain (as described in Harms 2013), nor can it form the basis of collective political action and negotiation with the state (as in Doshi 2013).

Understanding navigation as a process distinct from resistance or refusal aligns my argument with those of other urban scholars who have documented more subtle modes of living in oppressive conditions. Though some may look for examples of the dispossessed fighting for their rights "by staying in place, or claiming the right to stay in place, and demanding their proprietary rights in land" (Butler and Athanasiou 2013, 23), the responses of my informants reveal a very different approach to "staying in place." Staying in Mutuwall is not an act of resistance, but rather a form of endurance. Residents quietly "continue to continue" (Harker forthcoming, Simone 2014). Rather than fighting dispossession, they simply "deal with" it (Harker 2011) or find creative ways of "getting by" (Allen 2008).xvii This is particularly evident in William's story, which highlights the importance of strategies such as alternating fishing with 
other jobs or migrating as modes of survival in uncertain times. This ethnography has specifically pointed to this endurance as being shaped by the ideas of belonging to a national community; Colombo is thus an important site for understanding the variety of forms that dispossession can take, and for theorizing how these are linked with pre-existing loyalties and senses of citizenship.

As people across the Global North and South contend with ever-evolving forms of dispossession, it is increasingly obvious that ideas of national belonging, ethnicity and race are intimately connected with questions of class and capital. Mutuwall residents occupy an "edge" of both the aspirational global city and the hegemonic understanding of the Sri Lankan nation-state. And yet, even as they navigate unsettled waters, they continue to quietly claim a place as part of a broader national community. This ethnography is not an attempt at romanticizing precarity or uncritically siding with my interlocutors' nationalist rhetoric. Rather, this essay is a starting point for more critical, nuanced discussions not only of who is excluded and marginalized in various projects of global city-making, but of how those excluded navigate and make sense of their place in the world. Ultimately, thinking through the ways that people navigate dispossession affirms the uncertainty inherent in projects of capitalist urban development. The world-class city should be understood "as an aspirational condition, rather than an empirical reality" (Anjaria and McFarlane 2011, 14). Navigation, then, helps us see the world-class city not as an established object or fixed entity, but as a constantly changing, emergent social and material landscape.

\section{References}

Anjaria, Jonathan and McFarlane, Colin (eds.). 2011. Urban Navigations: Politics, Space and the City in South Asia. London and New Delhi: Routledge.

Allen, Lori. 2008. "Getting By the Occupation: How Violence became Normal during the Second Palestinian Intifada" Cultural Anthropology 23(3): 453-487. 
Amarasuriya, Harini and Spencer, Jonathan. 2015. "With That, Discipline Will Also Come to Them: The Politics of the Urban Poor in Postwar Colombo" Current Anthropology 56(S11): S66-S75.

Baviskar, Amita. 2002. "The Politics of the City" Seminar 56. http://www.indiaseminar.com/2002/516/516\%20amita\%20baviskar.htm

Butler, Judith and Athanasiou, Athena. Dispossession: The Performative in the Political. Polity Press.

Brow, James. 1990. "Notes on Community, Hegemony and the Uses of the Past." Anthropological Quarterly 63 (1):1-6. . 1996. Demons and Development: The Struggle for Community in a Sri Lankan Village. Phoenix: University of Arizona Press.

Centre for Policy Alternatives. 2014. "Forced Evictions in Colombo: The Ugly Price of Beautification" Centre for Policy Alternatives Report.

De Boeck, Filip. 2011. "Inhabiting Ocular Ground: Kinshasa's Future in the Light of Congo's Spectral Urban Politics." Cultural Anthropology 26 (2):263-286.

Doshi, Sapana. 2013. "The Politics of the Evicted: Redevelopment, Subjectivity, and Difference in Mumbai's Slum Frontier" Antipode 45(4): 844-865.

Fernandes, Leela. 2006. "The Politics of Forgetting: Class Politics, State Power and the Restructuring of Urban Space in India" Urban Studies 41(12): 2415-2430.

Fernandez, Bina. 2017. "Dispossession and the Depletion of Social Reproduction" Antipode 50(1): 142-163.

Ghertner, Asher D. 2015. Rule by Aesthetics: World-Class City Making in Delhi. Oxford: Oxford University Press.

Goldman, Michael. 2011. "Speculative Urbanism and the Making of the Next World City." International Journal of Urban and Regional Research 35 (3):555-581.

Harker, Chris. 2011. "Geopolitics and family in Palestine" Geoforum 42 (3): 306-315. . Forthcoming. Spacing Debt: Obligations, Violence and Endurance in Ramallah,

Palestine. Durham, N.C.: Duke University Press. (Autumn 2020)

Harms, Erik. 2011. Saigon's Edge: On the Margins of Ho Chi Minh City. Minneapolis: University of Minnesota Press.

. 2012. "Beauty as control in the new Saigon: Eviction, new urban zones, and atomized dissent in a Southeast Asian city." American Ethnologist 39 (4):735-750. . 2013. "Eviction time in the new Saigon: Temporalities of Displacement in the Rubble of Development." Cultural Anthropology 28 (2):344-368.

Holston, James. 2009. "Insurgent Citizenship in an Era of Global Urban Peripheries" City and Society 21(2): 245-267

Jazeel, Tariq. 2017. "Urban Theory with an Outside" Environment and Planning D: Society and Space 0(0): 1-15.

Jeganathan, Pradeep and Ismail, Qadri. (Eds) (1995) Unmaking the Nation: The Politics of Identity and History in Modern Sri Lanka Colombo: Social Scientists Association.

Li, Tania. 2009. "To Make Live or Let Die? Rural Dispossession and the Protection of Surplus Populations." Antipode 41 (S1):66-93.

Melly, Caroline. 2013. "Ethnography On The Road: Infrastructural Vision And The Unruly Present In Contemporary Dakar" Africa 83 (3):385 - 402. 
Nagaraj, Vijay Kumar. 2016. "From Smokestacks to Luxury Condos: The Housing Rights Struggle of the Millworkers of Mayura Place, Colombo" Contemporary South Asia 24(4): 429-443.

Perera, Iromi. 2016. "Living It Down: Life After Relocation in Colombo's High Rises: A Survey of Households Relocated by The Urban Regeneration Project" Centre for Policy Alternatives Report.

Pettit, Harry. 2018. "Hopeful City: Meritocracy and Affect in Global Cairo" International Journal of Urban and Regional Research, early online version.

Radicati, Alessandra. 2018. "Hub City: Aspiration and Dispossession in 21 st Century Colombo" PhD Dissertation, Department of International Development, London School of Economics and Political Science.

. 2019. "Island journeys: fisher itineraries and national imaginaries in Colombo," Contemporary South Asia, 27:3, 330-341.

Rampton, David. 2011. "'Deeper hegemony': the politics of Sinhala nationalist authenticity and the failures of power-sharing in Sri Lanka," Commonwealth \& Comparative Politics, 49:2, 245-273.

Robinson, Jennifer. 2016. "Thinking Cities Through Elsewhere: Comparative Tactics for a More Global Urban Studies" Progress in Human Geography 40(1): 3-29.

Roy, Ananya and Aihwa Ong, eds. 2011. Worlding Cities: Asian Experiments and the Art of Being Global: Wiley-Blackwell.

Roy, Ananya. 2009. "Why India Cannot Plan Its Cities: Informality, Insurgence and the Idiom of Urbanization" Planning Theory 8(1): 76-87.

. 2011. "Slumdog Cities: Rethinking Subaltern Urbanism" International Journal

of Urban and Regional Research 35(2): 223-238.

Simone, Abdoumaliq. 2014. Jakarta, Drawing the City Near. Minneapolis: University of Minnesota Press.

. 2016. "It's Just the City After All!" International Journal of Urban and Regional Research 40(1): 210-218.

Spencer, Jonathan and Amarasuriya, Harini. 2015. "With That, Discipline Will Also Come to Them": The Politics of the Urban Poor in Postwar Colombo." Current Anthropology 56 (Supplement 11):S66-S75.

Tennekoon, Serena N. 1988. "Rituals of development: the accelerated Mahaväli development program of Sri Lanka." American Ethnologist 15 (2):294-310.

Venugopal, Rajesh. 2018. Nationalism, Development and Ethnic Conflict in Sri Lanka. Cambridge: Cambridge University Press.

Vigh, Henrik. 2009. "Motion squared: a second look at the concept of social navigation" Anthropological Theory 9(4): 419-438.

Woost, Michael. 1993. "Nationalizing the local past in Sri Lanka: histories of nation and development in a Sinhalese village." American Ethnologist 20 (3):502-521.

Zeiderman, Austin. 2016. "Submergence: Precarious Politics in Colombia's Future Port City" Antipode 48(3): 809-831.

. 2018. "Beyond the Enclave of Urban Theory" International Journal of Urban and Regional Research early online version. 


\section{Acknowledgments}

This paper took many years to develop. First and foremost, I would like to thank my friends, acquaintances and informants in Colombo for opening their homes and lives to me. The arguments presented here benefitted greatly from generous engagement by audiences at the Futures and Ruins Workshop in 2016, held at Duke University; the Anthropology of Economy/Inclusive Economies Seminar at the London School of Economics and Political Science in 2016; from the insights of my PhD supervisors, Austin Zeiderman and Rajesh Venugopal; and invaluable comments on different drafts from Alyssa Miller, Michael Edwards, Danya Al-Saleh, Suzie Ferguson, Elizabeth DeLuca, Matthew Ghazarian, Alexandra Schindler and two anonymous reviewers. Finally, thanks to Tariq Jazeel and Andy Kent for their support and advice throughout the publishing process.

\section{Funding}

The support of the London School of Economics and Political Science (LSE) PhD scholarship, the American Institute for Sri Lankan Studies Sinhala Language Grant, and a PhD research award from the University of California Berkeley Institute for South Asian studies are gratefully acknowledged.

\section{Endnotes}

i To protect my research participants' privacy, all names used in this text are pseudonyms and some identifying information has been changed.

ii For a more developed account of how resistance has been theorized in geography specifically, see Hughes 2019. iii For an extended discussion of 20th and 21st century patterns of mobility among fishers in Mutuwall, see Radicati 2019.

iv There is considerable ambiguity surrounding exactly how many "slums" actually exist in Colombo (Nagaraj 2016). Labelling specific communities as "under-served" is a politically-charged act which often paves the way for eviction.

v Interviews took place with in a mix of English and Sinhala, with the help of a Sinhala-speaking research assistant. vi Other waves of dispossession which figured in my conversations with fishers included the implementation of a High Security Zone which prevented fishers from entering particularly areas of Colombo's waters to pursue their catches, and the lingering social and material effects of the 2004 Boxing Day tsunami. See Radicati 2019 for further discussion of these.

vii Fishers' appearance was often commented on in a derogatory fashion by other Colombo residents; in particular, the association of fishermen with dark complexions and rough skin added to their exclusion from elite Colombo. Visual markers were thus a legitimate concern for fisherman when weighing whether they would be allowed on or near the site of the Port City.

viii Green cards are documents issued by the municipal council indicating tenure, however they are not the same as deeds and do not equate with ownership; the possession of a green card counters the claim that the displaced in Colombo are "illegally" encroaching on land (Perera 2016).

ix Thanks to an anonymous reviewer for this observation.

x See Pettit (2018) for a helpful discussion of the expectation of resistance in emerging global cities.

xi Mutuwall residents frequently invoked "the country" as an entity to which they owed loyalty. In Sinhala, rate refers to "country," while jatiya refers to nationality in the sense of ethnicity or provenance. Jatiya usually denotes the different ethnicities of the island, with Tamils, Muslims and Sinhalese forming separate jatiya. In our

conversations, Mutuwall residents never invoked jatiya as a concept, but commonly appealed to rate. This may be a function of precisely the ambiguous, marginal position they occupy vis-a-vis Sinhala-Buddhism, which I have discussed elsewhere (Radicati 2019).

xii For an expanded analysis of these discussions surrounding the Port City, see Radicati (2018).

xiii For a recent and particularly cogent account of scholarly debates on Sinhala nationalism, see Venugopal (2018). 
xiv Thanks are due to an anonymous reviewer for raising this important question.

$\mathrm{xv}$ This leads to a consideration of my own positionality and the possibility that these statements were being performed for me as the ethnographer. However, as a white foreigner, most Sri Lankans would not assume that I personally had any investment in the Rajapakse government or the Port City - if anything, most of my informants would have assumed the opposite, that as a westerner I was pre-disposed to be critical of any project initiated under the former President. The presence of my research assistant, a Sinhala-Buddhist male, could have had some bearing on these utterances. However, given that he was seen working with and accompanying a western researcher, and in light of the factors mentioned previously, I do not believe this would have heavily impacted their decision to make these claims.

xvi Serena Tennekoon (1988) suggested that development was the most important agenda of the Sri Lankan state; though it was briefly replaced by the national security agenda, ultimately she argues that development has been the structuring logic/drive of postcolonial Sri Lanka.

xvii Harker (2011 and forthcoming) and Allen (2008) develop their concepts of "dealing with," "enduring" and "getting by" respectively through ethnographic research in Palestine, detailing the effects of Israeli occupation. It is worth noting that these related terms spring from a distinct empirical context, specifically one of settler-colonial violence in which those who deploy these forms of survival are understood as non-citizens. In the context I have described in Mutuwall, fishers' identity claims are in fact centered on same-ness, belonging and citizenship. 